\title{
PENERAPAN QUANTUM TEACHING MELALUI STRATEGI GROUP STUDY BERBANTUAN MODUL
}

\author{
Aini Indriasih (aini@ut.ac.id) \\ UPBJJ-UT Semarang
}

\begin{abstract}
In the teaching and learning process there is a strong interrelationship of teachers, students, curiculum, equipment and infrastructure. The teacher is to select models and media which are appropriate to the learning material and hopefully this will stimulate students' interest in learning. This study of modular quantum teaching is an experimental research as an alternative to overcome teachers'problems in achieveing the learning objectives, especially in the learning of social science in elementary schools. Study was done in the Elementary Schools 06 of Cendono Kudus in 2010. The samples were taken through a cluster sampling technique and assigned into an experimental group and a control group. The data of activeness and process skills were taken through observation and achievement test. The obtained data were descriptively presented and analyzed through variant analysis. The study showed that the learning activeness of modular quantum teaching group was categorized as learning active. Meanwhile the process skills and learning activeness of expository group were categorized as skilful. Based on the test of influence, process skills, motivation and students' activeness of modular quantum teaching group had $4.9 \%$ of influence and other factors had $95.1 \%$ of influence. The t-test showed different learning achievement of the two groups. The mean score of experimental group was higher than that of control group.
\end{abstract}

Keywords: modular quantum teaching

Dalam proses belajar mengajar di kelas guru mempunyai tugas untuk memilih model dan media pembelajaran yang tepat, sesuai dengan materi yang disampaikan tujuan pendidikan tercapai dengan efektif. Banyak siswa merasa kesulitan memahami suatu masalah dalam pembelajaran karena mereka tidak tahu bagaimana menemukan langkah-langkah yangdiperlukan untuk menyelesaikannya Sobel (2004). Lebih lanjutdinyatakan bahwa pembelajaran yang dilakukan guru, dengan menggunakan alat peraga dapat membuat situasi menjadi nyata bagi siswa sehingga membantu memotivasi siswa dan mampu membangkitkan minat siswa terhadap persoalan yang dihadapi. Salah satu media pembelajaran tersebut adalah dengan media modul.

Selain itu Silberman, (2007) mengatakan bahwa strategi Group Study memberikan siswa tanggung jawab untuk mempelajari materi pelajaran dan menjelaskan isinya dalam kelompok tanpa kehadiran pengajar. Tugas yang diberikan pada siswa perlu cukup spesifik untuk menjamin bahwa hasil sesi belajar akan efektif dan kelompok akan mampu mengatur diri.

Strategi pembelajaran Group Study diharapkan dapat menimbulkan keaktifan sekaligus kreativitas dan motivasi siswa dalam mempelajari IPS, karena salah satu tujuan pendidikan IPS adalah mengembangkan aspek pengetahuan, sikap, dan nilai yang berkaitan dengan kehidupan 
bermasyarakat, sehingga siswa dapat memperoleh manfaat yang optimal baik dari proses maupun hasil belajarnya.

Dalam upaya meningkatkan hasil belajar, penggunaan media pembelajaran, pemilihan strategi serta metode mutlak dilakukan, salah satu media yang perlu dikembangkan dalam penelitian ini adalah modul. Modul sangat praktis dan menarik untuk dipelajari, memungkinkan digunakan dalam berbagai keadaan/ tempat, baik di sekolah maupun di rumah, serta yang paling utama adalah dapat memenuhi nilai atau fungsi media pembelajaran secara umum. Selain itupenerapan model pembelajaran Quantum Teaching dengan didampingi modul serta media pembelajarandiharapkan dapat meningkatkan aktivitas siswa, meningkatkan ketuntasan hasil belajar siswa, serta meningkatkan kualitas pembelajaran.Penerapan Quantum Teaching diharapkan juga dapat memotivasi belajar siswa.

Salah satu prinsip pelaksanaan Kurikulum Tingkat Satuan Pendidikan (KTSP)adalah kurikulum dilaksanakan dengan menegakkan kelima pilar belajar yaitu: (1) Belajar untuk beriman dan bertakwa kepada Tuhan Yang Maha Esa. (2) Belajar untuk memahami dan menghayati. (3) Belajar untuk mampu melaksanakan dan berbuat secara efektif. (4) Belajar untuk hidup bersama dan berguna bagi orang lain dan (5) Belajar untuk membangun dan menemukan jati diri, melalui proses pembelajaran yang aktif, kreatif, efektif, dan menyenangkan. Guru sebagai ujung tombak transfer ilmu harus memiliki kreativitas yang tinggi. Guru harus selalu mengupayakan pembelajaran di kelas dapat membuahkan hasil yang bermakna sesuai dengan tuntutan kurikulum dan tuntutan zaman, Namun demikian guru juga di hadapkan dengan respon negatif siswa terhadap mata pelajaran yang kurang disukai .

Dengan berpedoman pada prinsip pelaksanaan KTSP seorang guru diharapkan mampu mengembangkan strategi pembelajaran yang bervariasi. Strategi Group Study berbantuan modul yang bernuansa Quantum Teachingdipandang sesuai dengan tujuan pembelajaran yang digariskan dalam KTSP. Hal ini dikarenakandapat meningkatkan aktivitas siswa, meningkatkan ketuntasan hasil belajar siswa, meningkatkan kualitas pembelajaran, dan dapat memotivasi belajar siswa.

Permasalahan yang muncul selama ini adalah rendahnya motivasi siswa serta kurangnya pencapaian indikator pembelajaran IPS dikarenakan materi yang terlalu banyak. Di samping itu juga disebabkan oleh kurang efektifnya proses pembelajaran dan guru belum menggunakan strategi pembelajaran yang bervariasi.

Perkembangan dalam dunia pendidikan yang semakin pesat dengan adanya berbagai penelitian menemukan sebuah pendekatan pengajaran yang disebut dengan Quantum Teaching Quantum diartikan sebagai interaksi yang menggubah (mengorkestrasi) energi menjadi cahaya. Interaksi menggubah kemampuan dan bakat alamiah siswa, yang diharapkan bermanfaat bagi mereka sendiri dan bagi orang lain (De Porter, \& Mike, 2007). Quantum Teaching menciptakan lingkungan belajar yang efektif, dengan cara menggunakan unsur yang ada pada siswa dan lingkungan belajarnya melalui interaksi yang terjadi di dalam kelas.

Pengajaran dengan Quantum Teaching tidak hanya menawarkan materi yang harus dipelajari siswa, namun lebih dari itu, siswa juga diajarkan bagaimana menciptakan hubungan emosional yang baik dalam dan ketika belajar. Asas utama Quantum Teaching terletak pada kemampuan guru untuk menjembatani jurang antara dunia guru dengan dunia siswa.

Terdapat empat aspek untuk menata panggung belajar dalam Quantum Teaching, yaitu suasana, landasan, lingkungan, dan rancangan. Suasana kelas mencakup bahasa yang dipilih, cara menjalin simpati dengan siswa, dan sikap guru terhadap sekolah serta belajar. Suasana yang penuh kegembiraan membawa kegembiraan pula dalam belajar. 
Quantum Teaching menjadikan guru lebih kreatif, memotivasi guru untuk terus meningkatkan kemampuan dalam mengajar. Kegiatan mengajar adalah kegiatan yang sangat menguras energi. Mengajar bukanlah sekedar memberi atau menyampaikan sesuatu. Mengajar sesungguhnya adalah memotivasi, membangkitkan gairah guru dan murid untuk belajar apa saja dan dimana saja serta kapan saja (Hernowo, 2006). Quantum Teaching mengajarkan agar proses belajar mengajar di kelas dapat bermakna.

Pada saat menyampaikan materi Quantum Teaching, lebih lanjut Hernowo (2006) menekankan bahwa guru pada saat mengajar haruslah mengajar dengan segenap kekuatan hati, dengan demikian akan tercipta proses belajar yang dinamis dan tidak terlupakan.

Media pembelajaran meningkatkan proses belajar siswa diharapkan dapat meningkatkan hasil belajar siswa. Menurut Sudjana dan Rivai (2002) ada beberapa alasan mengapa media pembelajaran dapat mempertinggi proses belajar siswa. Taraf berpikir manusia mengikuti tahap perkembangan dimulai dari berpikir konkret menuju ke berpikir abstrak, dimulai dari berpikir sederhana menuju ke berpikir kompleks. Penggunaan media pembelajaran erat kaitannya dengan tahapan berpikir tersebut sebab melalui media pembelajaran hal-hal yang abstrak dapat dikonkretkan, dan hal-hal yang kompleks dapat disederhanakan (Sudjana, \& Rivai, 2002).

Penggunaan media pembelajaran sangat bergantung pada tujuan pengajaran, bahan pengajaran, kemudahan memperoleh media yang diperlukan serta kemampuan guru dalam menggunakannya dalam proses pengajaran. Dalam pembelajaran Quantum Teaching, penggunaan media pembelajaran sebagai alat bantu tidak hanya membantu pembelajaran visual, tetapi dapat pula membantu modalitas kinestetik yang mengakses segala jenis gerak dan emosi, diciptakan maupun diingat (De Porter, \& Mike, 2007).

Moduldapat dirumuskan sebagai: suatu unit yang lengkap yang berdiri sendiri dan terdiri atas suatu rangkaian kegiatan belajar yang disusun untuk membantu siswa mencapai sejumlah tujuan yang dirumuskan secara khusus. Modul dapat memuat berbagai macam kegiatan belajar seperti membaca, memperhatikan gambar, melihat film, mendengarkan audio, melaksanakan demonstrasi serta eksperimen. Hal ini seiring dengan model pembelajaran Quantum Teaching yang menginteraksikan unsur-unsur untuk belajar efektif yang mempengaruhi kesuksesan belajar, menciptakan lingkungan belajar yang efektif, dengan cara menggunakan unsur yang ada pada siswa dan lingkungan belajarnya melalui interaksi yang terjadi di dalam kelas (De Porter, \& Mike, 2007).

Tujuan dari pengajarandengan modul antara lain membuka kesempatan bagi siswa untuk belajar menurut kecepatan dan menurut caranya masing-masing, memberikan kesempatan untuk memilih diantara sekian banyak topik dalam satu program, mengadakan penilaian tentang kemajuan dan kelemahan siswa, dan memberikan modul remidial. Penggunaan modul memberikan beberapa keuntungan bagi siswa, antara lain memberikan balikan atau feedback, dapat disesuaikan dengan kemampuan siswa secara individual, memberi secara khusus pelajaran remedial, dan memberikan evaluasi formatif (Nasution, 2003).

\section{Pembelajaran IImu Pengetahuan Sosial di SD}

Berkaitan dengan pembelajaran Ilmu Pengetahuan Sosial (IPS) di SD Martorella dalam Solihatin dan Raharjo (2007) berpendapat bahwa pembelajaran IPS lebih menekankan pada aspek pendidikan dari pada transfer konsep, karena dalam pembelajaran IPS siswa diharapkan memperoleh pemahaman terhadap sejumlah konsep dan mengembangkan serta melatih sikap, nilai, moral, dan keterampilannya berdasarkan konsep yang telah dimilikinya. Dengan demikian pembelajaran IPS harus diformulasikan pada aspek pendidikan. 
Adapun tujuan pembelajaran IPS, adalah untuk mempersiapkan siswa menjadi warga negara yang baik dalam kehidupan di masyarakat (Gross dalam Solihatin \& Raharjo, 2007). Tujuan lain menurut Gross dalam Solihatin dan Raharjo (2007). Pendidikan IPS untuk mengembangkan kemampuan siswa menggunakan penalaran dalam mengambil keputusan setiap masalah yang dihadapi. Pengajaran IPS hendaknya disesuaikan dengan: (1) tingkat perkembangan siswa; (2) pengalaman belajar dan lingkungan budaya siswa; (3) kondisi kehidupan masyarakat sekitar masa kini dan kelak yang diharapkan; (4) proyeksi harapan pembangunan nasional/daerah yang tentunya mampu menjangkau dan diperankan siswa kini dan kelak kemudian hari; dan (5) isi dan pesan nilai moral budaya bangsa, Pancasila dan agama yang dianut dan diakui bangsa dan Negara Indonesia (Kosasih, 1995)

Jarolimek (1993) menyatakan bahwa tujuan pendidikan IPS hendaknya mampu mengembangkan aspek pengetahuan dan pengertian, aspek sikap dan nilai, dan aspek keterampilan pada diri siswa. Aspek pengetahuan dan pemahaman siswa tentang dunia dan kehidupan masyarakat di sekitarnya, aspek sikap berkaitan dengan pemberian bekal mengenai dasar etika dan norma yang nantinya menjadi orientasi nilai dalam kehidupan di masyarakat, sedangkan aspek keterampilan meliputi keterampilan sosial dan mampu bekerja sama dengan orang lain dalam kehidupan sehari-hari.

Schunke (1988) mengatakan bahwa pendidikan IPS mengembangkan tiga kemampuan dasar siswa, yaitu kemampuan penguasaan bidang pengetahuan (knowing), kecakapan melaksanakan kegiatan untuk menguasai sejumlah pengetahuan dari berbagai sumber belajar (doing) serta apresiasi, penguasaan dan penginternalisasian bidang nilai dan sikap untuk menjadi manusia seutuhnya (caring). Ketiga kemampuan dasar ini memiliki kaitan yang sangat erat dan bersifat paralel, sehingga kemampuan dasar ini perlu dikembangkan secara seimbang. Dengan demikian peranan pendidikan IPS sangat penting untuk mendidik siswa mengembangkan pengetahuan, sikap, dan keterampilan untuk dapat mengambil bagian secara aktif dalam kehidupannya kelak sebagai anggota masyarakat dan warga negara yang baik (Somantri, 1997; Waterwrot, 2000)

Penelitian ini dilakukan dengan tujuan sebagai berikut.

1. Mengetahui perbedaan motivasi belajar, dan hasil belajar IPS antara model pembelajaran dengan model Group Study berbantuan modul dan ekspositori.

2. Mendiskripsikan keaktifan dan keterampilan siswa dalam mengikuti proses pembelajaran yang menggunakan model pembelajaran Group Study berbantuan modul dan ekspositori.

3. Mengetahui peningkatan standar ketuntasan belajar IPS bila proses pembelajaran menggunakan model pembelajaran Group Study berbantuan modul.

\section{METODOLOGI}

Penelitian ini merupakan penelitian dengan desain eksperimenyang dilaksanakan di SD Negeri 01 dan 06 Cendono Kabupaten Kudus.Sampel penelitian ini terdiri dari 35 siswa sebagai kelompok eksperimen 35 siswa sebagai kelompok kontrol.

Uji homogenitas untuk proses pengambilan kelas kontrol dan kelas eksperimen dilakukan dengan pengambilan nilai IPS siswa pada awal sebelum diberi perlakuan. Berdasarkan hasil uji homogenitas tersebut peneliti dapat menentukan kelas eksperimen dan kelas kontrol secara bebas dari kedua kelas tersebut. Untuk menguji apakah ada perbedaan rerata, dalam hal ini akan dipakai sebagai pertimbangan menentukan rumus beda denganAnalisis Varians. 
Pada penelitian ini variabel bebas adalah penggunaan strategi Group Study berbantuan modul (X1) terdiri dari X1.1 adalah keaktifan siswa dalam quantum teaching, X1.2adalah keterampilan siswa dalam quantum teaching, X1.3 adalah motivasi siswa dalam quantum teachingdengan strategi Group Study berbantuan modul.Kelompok kontrol dengan strategi ekspositori (X2) terdiri dari X2.1 adalah keaktifan siswa, X2.2 keterampilan siswa, X2.3 adalah motivasi siswa dalam pembelajaran dengan strategi ekspositori.

Pada penelitian ini variabel terikatnya adalah prestasi IPS siswa. Y1 adalah prestasi belajar siswa dengan strategi Group Study berbantuan modul dan Y2 adalah prestasi belajar siswa dengan strategi ekspositori.

Perhitungan reliabilitas diperoleh harga reliabilitas instrumen sebesar 0,702. Dari harga reliabilitas instrumen yang diperoleh dengan $r$ product-moment dengan $\mathrm{N}=30$ dan $5 \%$ sebesar 0,361 , maka dapat disimpulkan bahwa instrumen tersebut reliabel.

Uji coba instrumen dilakukan untuk memperoleh instrumen yang valid sehingga diharapkan data yang diperoleh juga dapat dipertanggung jawabkan.

Untuk menguji hipotesis yang telah dirumuskan, dalam penelitian initeknik analisis data yang digunakan adalah Analisis Varians. Untuk memenuhi persyaratan statistik, maka diadakan uji prasyarat analisis dengan uji normalitas data dan homogenitas varian.

Dari perhitungan(Kolmogorov-Smirnov)dapat dilihat berdasarkan nilai pretes diperoleh untuk kelas $X 1, X_{2}$, tingkat kritiknya berturut-turut adalah 0,204, dan 0,096, ternyata semua taraf kritiknya lebih dari 0,05 . Berdasarkan hasil tersebut, maka dapat dikatakan kedua sampel berasal dari populasi yang berdistribusi normal.

Homogenitas variansdiuji dengan menggunakan teknik Lavene. Berdasarkan perhituganTest of Homogeneity of Variances diperoleh bahwa nilai significant $=0,382$. Karena 0,382 $>0,05$ maka $\mathrm{H}_{0}$ diterima. Jadi kedua varians tersebut sama signifikan. Ini berarti bahwa kedua kelas berangkat dari sebaran kemampuan awal yang relatif sama, sehingga bila diberi perlakuan yang berbeda-beda maka akan timbul perbedaan sebagai akibat dari perlakuan-perlakuan tersebut, bukan dari perbedaan sebaran kemampuan awal.

\section{HASIL DAN PEMBAHASAN}

Dari hasil penelitian yang telah dilaksanakan, dapat dilaporkan hasil pengamatan variabel keterampilan proses, dan nilai hasil belajar sebagaimana pada Tabel 1.

Tabel 1. Analisis Statistik Hasil Belajar Kelompok Kontrol (Eekspositori) dan Kelompok Eksperimen (Group Study Berbantuan Modul)

\begin{tabular}{lcc}
\hline Statistik & \multicolumn{2}{c}{ Nilai hasil belajar (skala 0 - 100) } \\
\hline & & Metode ekspositori(kontrol) \\
Mean & $\begin{array}{c}\text { Metode Group Study } \\
\text { berbantuan Modul) }\end{array}$ \\
Median & 57,67 & 82,14 \\
Mode & 55,00 & 85,00 \\
Standar deviasi & 54,00 & 80,00 \\
Varians & 9,17 & 14,77 \\
Minimum & 33,00 & 218,07 \\
Maksimum & 42,00 & 35,00 \\
Jumlah & 75,00 & 100,00 \\
\hline
\end{tabular}


Dari skoring hasil analisis kelas kontrol dapat dideskripsikan bahwa nilai median 55 artinya ada separuh responden (17 siswa) total nilainya di atas 55 dan separuh lagi sebaliknya. Diperoleh mode 54 artinya kebanyakkan responden mendapat total nilai 54 . Selanjutnya mengurangi dan menambah nilai rata-rata dengan dua kali nilai standar deviasi $(57,667-2 \times 9,17=39,327$ dan $57,667+2 \times 9,17=76,007$ ) nilai tersebut berada di luar selang atau rentang nilai minimum $=42$ dan nilai maksimum 75 . Hal tersebut menunjukkan variabel hasil belajar kelas kontrol mempunyai nilai standar deviasi besar.

Karena nilai median 55 maka dapat dikatakan hasil belajar kelas kontrol belum mengalami ketuntasan belajar

Dari skoring analisis hasil belajar kelas eksperimen dengan Group Study berbantuan modul dapat dideskripsikan bahwa nilai median 85 artinya ada separoh siswa memiliki total nilai di atas 85 dan separoh lagi sebaliknya. Diperoleh mode80jadi kebanyakkan siswa mendapat total nilai 80

Selanjutnya mengurangi dan menambah nilai rata-rata dengan dua kali nilai standar deviasi $(82,14-2 \times 14,76=52,38$ dan $82,14+2$ x 14,76=111,66) nilai tersebut berada dalam selang atau rentang nilai minimum $=35$ dan nilai maksimum 100

Karena nilai hasil analisis kelas eksperimen dengan Group study berbantuan modul dapat dideskripsikan bahwa nilai mode80 maka dapat dikatakan hasil belajar kelas eksperimen dengan Group study berbantuan modul mengalami ketuntasan belajar. Untuk ketuntasan belajar siswa digunakan acuan yang termuat dalam KTSP tahun 2008, yaitu: "Seorang siswa dinyatakan tuntas belajar apabila memiliki daya serap $>65 \%$. Ketuntasan klasikal tercapai apabila $>85 \%$ siswa pada suatu kelas tuntas belajar (Depdiknas, 2008)

\section{Pengaruh keaktifan siswa dalam pembelajaran dengan Group Study berbantuan modul pada hasil belajar.}

Tujuan dari analisis regresi ini data adalah untuk menguji pengaruh variabel keaktifan siswa dalam pembelajaran dengan strategi Group Study berbantuan modul terhadap variabel hasil belajar dari siswa.

Ada 2 Hipotesis, yaitu:

Hipotesis 1

Keaktifan siswa dalam pembelajaran dengan strategi Group Study tidak mempunyai hubungan linier terhadap hasil belajar para siswa.

Hipotesis 2.

Keaktifan siswa dalam pembelajaran dengan strategi Group Study mempunyai hubungan linier terhadap hasilbelajar para siswa.

Hasil yang diperoleh suatu persamaan regresi.

Tabel 2 . Coefficients, untuk Mendapatkan Persamaan Regresi.

\section{Coefficients $^{a}$}

\begin{tabular}{ccccccc}
\hline \multirow{2}{*}{ Model } & \multicolumn{2}{c}{$\begin{array}{c}\text { Unstandardized } \\
\text { coefficints }\end{array}$} & \multirow{2}{*}{$\begin{array}{c}\text { Standardized } \\
\text { Coefficients Beta }\end{array}$} & \multirow{2}{*}{ t } & Sig \\
\cline { 3 - 4 } & & $\mathrm{B}$ & Std Error & & & \\
\hline \multirow{2}{*}{1} & (costant) & 9,942 & 9,381 & 0,805 & 1,060 & 0,296 \\
& Akt GS & 0,909 & 106 & & 0,574 & 0,000 \\
\hline
\end{tabular}

a. Dependent Variable: HBGS 
Bentuk persamaan regresi Estimasi: $\quad \hat{Y}=9,942+9,381 X$ kita lihat Tabel 3.

Selanjutnya, untuk menguji bentuk persamaan regresi tersebut, diterima atau ditolak,dapat

Tabel 3.Anova, Dipakai untuk Menguji Menerima atau Menolak Hipotesis.

ANOVA $^{b}$

\begin{tabular}{lcrcrc}
\hline Mean & $\begin{array}{l}\text { Sum of } \\
\text { Square }\end{array}$ & df & Mean Square & F & Sig \\
\hline Regression & 2558,166 & 1 & 2558,166 & 73,519 & $0,000^{a}$ \\
Residual & 1391,834 & 34 & 34,796 & & \\
Total & 3950,000 & 35 & & & \\
\hline
\end{tabular}

a. Predictors ( Constant) AktGS

b. Dependent Variable HBGS

Berdasarkan output Anova, didapatkan bahwa nilai Sig 0,000=0\% lebih kecil dari 5\%. Dalam hal ini dipilih $\alpha=0,05=5 \%$. Maka sig $(=0,000)<\alpha(=0,05)$, yang berarti bahwa $H_{O}$ ditolak atau $H_{1}$ diterima.

Keaktifan siswa dalam pembelajaran dengan strategi Group Study mempunyai hubungan linier terhadap hasil belajar siswa. Karena linear dan nilai b juga positif, maka dalam keadaan ini menunjukkan adanya pengaruh positif $X$ terhadap $Y$.

Maka dapat dilanjutkan dengan melihat hasil output berikutnya untuk melihat seberapa besar kontribusi $\mathrm{X}$ terhadap $\mathrm{Y}$.

Tabel 4. Model Summary

\begin{tabular}{lcccc}
\hline Model & $\mathrm{R}$ & $\mathrm{R}$ Square & $\begin{array}{c}\text { Adjusted R } \\
\text { Square }\end{array}$ & $\begin{array}{c}\text { Std Error of } \\
\text { The Estimate }\end{array}$ \\
\hline 1 & $0,805^{a}$ & 0,648 & 0,639 & 5,8988 \\
\hline
\end{tabular}

a. predictor (Constant).AktGS

Besar keaktifan siswa dalam pembelajaran dengan strategi Group Study terhadap hasil belajar para siswa dapat dilihat pada nilai $R^{2}$ ( $R$ square) $=0,648$ atau $=64,8 \%$ (menunjukkan nilai yang cukup). Artinya $X$ mempengaruhi $Y$ sebesar $64,8 \%$, masih ada pengaruh variabel lain sebesar $35,2 \%$.

\section{Pengaruh keterampilan proses pembelajaran dengan strategi Group Study pada hasil belajar.}

Seperti telah diuraikan di atas bahwa hasil belajar sudah diuji normalitasnya, jadi bisa dilanjutkan untuk dilihat hasil analisis regresi antara keterampilan proses terhadap hasil belajar.

Tujuan dari analisis regresi data disini adalah untuk menguji pengaruh variabel keterampilan proses pembelajaran dengan strategi Group Study terhadap variabel hasil belajar dari siswa, dengan menggunakan bantuan program SPSS.

Ada 2 Hipotesis, yaitu: 
Hipotesis I.

Ketrampilan berproses pembelajaran dengan strategi Group Study tidak mempunyai hubungan linier terhadap hasil belajar siswa.

Hipotesis 2.

Ketrampilan berproses pembelajaran dengan strategi Group Study mempunyai hubungan linier terhadap hasil belajar siswa.

Hasil yang diperoleh suatu persamaan regresi.

Tabel 5. Tabel Coefficients, untuk Mendapatkan Persamaan Regresi.

Coefficients $^{a}$

\begin{tabular}{|c|c|c|c|c|c|c|}
\hline & \multirow[b]{2}{*}{ Model } & \multicolumn{2}{|c|}{$\begin{array}{l}\text { Unstandardized } \\
\text { coefficints }\end{array}$} & \multirow{2}{*}{$\begin{array}{c}\begin{array}{c}\text { Standardiz } \\
\text { ed } \\
\text { Coefficient }\end{array} \\
\text { S } \\
\text { Beta }\end{array}$} & \multirow[b]{2}{*}{$\mathrm{t}$} & \multirow[b]{2}{*}{ Sig } \\
\hline & & B & Std Error & & & \\
\hline 1 & $\begin{array}{l}\text { (costant) } \\
\text { tramp QT }\end{array}$ & $\begin{array}{c}15,453 \\
0,854\end{array}$ & $\begin{array}{c}9,347 \\
107\end{array}$ & 0,785 & $\begin{array}{l}1,653 \\
8,017\end{array}$ & $\begin{array}{l}0,106 \\
0,000\end{array}$ \\
\hline
\end{tabular}

a. Dependent Variable: HBGS

Bentuk persamaan regresi Estimasi: $\hat{Y}=15,453+9,347 X$ kita lihat Tabel 6.

Selanjutnya, untuk menguji bentuk persamaan regresi tersebut, diterima atau ditolak, dapat

Tabel 6. Anova, Dipakai untuk Menguji Menerima atau Menolak Hipotesis.

ANOVA $^{b}$

\begin{tabular}{clrrrrc}
\hline Mean & & Sum of & & & & \\
& & Square & df & Mean Square & \multicolumn{1}{c}{ F } & Sig \\
\hline & Regression & 2434,715 & 1 & 2434,715 & 64,271 & $0,000^{a}$ \\
& Residual & 1515,285 & 40 & 37,882 & & \\
& Total & 3950,000 & 41 & & & \\
\hline
\end{tabular}

a. Predictors ( Constant) KetrGS

b. Dependent Variable HBGS

Berdasarkan output SPSS pada tabel Anova, didapatkan bahwa nilai Sig $=0,000=0 \%$ lebih kecil dari 5\%. Dalam hal ini dipilih $a=0,05$.

Maka sig $(=0,000)<a(=0,05)$, yang berarti bahwa $H_{O}$ ditolak atau $H_{1}$ diterima.

Maka keaktifan proses pembelajaran dengan strategi Group Study mempunyai hubungan linier terhadap hasil belajar siswa.

Karena linear dan nilai b juga positif, maka dalam keadaan ini menunjukkan adanya pengaruh positif $X$ terhadap $Y$. Maka dapat dilanjutkan dengan melihat hasil output berikutnya untuk melihat seberapa besar kontribusi X terhadap Y. Ditunjukkan pada Tabel 7. 
Tabel 7. Model Summary

\begin{tabular}{lcccc}
\hline Model & $\mathrm{R}$ & $\mathrm{R}$ Square & $\begin{array}{c}\text { Adjusted R } \\
\text { Square }\end{array}$ & $\begin{array}{c}\text { Std Error of } \\
\text { The Estimate }\end{array}$ \\
\hline 1 & $0,785^{a}$ & 0,616 & 0,607 & 6,1548 \\
\hline
\end{tabular}

a. predictor ( Constant). Ketrp GS

Besar keaktifan berproses pembelajaran dengan strategi Group Study terhadap hasil belajar siswa dapat dilihat pada nilai $R^{2}$ ( $R$ square) $=0,616$ atau $=61,6 \%$ (menunjukkan nilai yang cukup). $38,4 \%$.

Artinya $\mathrm{X}$ mempengaruhi $\mathrm{Y}$ sebesar $61,6 \%$, masih ada pengaruh variabel lain sebesar

\section{Uji Hipotesis Pada Kelas Eksperimen dengan Group Study berbantuan modul}

Untuk menguji ada tidaknya pengaruh motivasi, keterampilan, keaktifan siswa secara bersama-sama terhadap hasil belajar siswa perlu dilakukan uji analisis data dengan SPSS versi 13.0. $\mathrm{H}_{0}: \beta=0$, motivasi, keterampilan, keaktifan siswa tidak linear terhadap hasil belajar (hubungan tidak berarti)

$\mathrm{H}_{1}: \beta \neq 0$, motivasi, keterampilan, keaktifan siswa linear terhadap hasil belajar (hubungan berarti)

Untuk melihat besar pengaruh atau kontribusi motivasi, keterampilan, keaktifan siswa $(X)$ terhadap hasil belajar $(Y)$ dapat dibaca dari nilai $R$ Square.

Tabel 8. Model Summary (b)

\begin{tabular}{|c|c|c|c|c|c|c|c|c|c|c|}
\hline \multirow[b]{2}{*}{ Model } & \multirow[b]{2}{*}{$\mathrm{R}$} & \multirow[b]{2}{*}{$\begin{array}{c}\mathrm{R} \\
\text { Square }\end{array}$} & \multirow[b]{2}{*}{$\begin{array}{l}\text { Adjusted } \\
\text { R Square }\end{array}$} & \multirow{2}{*}{$\begin{array}{l}\text { Std. Error } \\
\text { of the } \\
\text { Estimate }\end{array}$} & \multicolumn{5}{|c|}{ Change Statistics } & \multirow[b]{2}{*}{$\begin{array}{l}\text { Durbin- } \\
\text { Watson }\end{array}$} \\
\hline & & & & & $\begin{array}{c}\mathrm{R} \\
\text { Square } \\
\text { Change }\end{array}$ & $\begin{array}{c}\mathrm{F} \\
\text { Change }\end{array}$ & $\mathrm{df1}$ & df2 & $\begin{array}{c}\text { Sig. } \\
\text { F } \\
\text { Change }\end{array}$ & \\
\hline 1 & 0,220 & 0,049 & $-0,043$ & 15,08457 & 0,049 & 0,528 & 3 & 31 & 0,666 & 1,857 \\
\hline
\end{tabular}

(a)

\footnotetext{
a Predictors: (Constant), Motiv, Keakt, Ketrp

b Dependent Variable: HasB
}

Nilai $R$ square menunjukkan besarnya kontribusi $X$ yaitu motivasi, keterampilan, keaktifan siswa terhadap Y nilai hasil belajar. Dari Tabel 8 dapat dilihat nilai $R^{2}=0,49=49 \%$, artinya motivasi, keterampilan, keaktifan siswa mempengaruhi hasil belajar sebesar $49 \%$, sedangkan masih ada pengaruh variabel lain sebesar $51 \%$.

\section{Uji Hipotesis Pada Kelas eksperimen dan Kelas Kontrol}

Uji Perbedaan Rata-Rata

Analisis varian digunakan untuk membandingkan dua atau lebih varibel acak.

Ho : $\beta_{1}=\beta_{2}=\ldots=\beta_{1}=0$

Ha : tidak semua sama dengan nol. 
Kita akan membandingkan ke dua nilai hasil penelitian yaitu antara kelas kontrol, dan kelas eksperimen dengan Group Study berbantuan modul.

$$
\begin{gathered}
\mathrm{Ho}: \beta_{1}=\beta_{2}=\beta_{3}=\beta_{4} \begin{array}{l}
\text { artinya tidak ada perbedaan rerata antara kelas kontrol, dengan } \\
\text { kelaseksperimen berbantuan modul }
\end{array}
\end{gathered}
$$

$\mathrm{Hi}$ : tidak semua sama antara antara kelas kontrol, dengan kelas eksperimen

Pada tabel Anova tersebut terlihat sig = 0,000 kurang dari 5\% maka signifikan Ho ditolak artinya terdapat perbedaan antara kelas kontrol dengan kelas eksperimen dengan group Study berbantuan modul.

Nilai mean dari kelas kontrol adalah 57,667nilai mean dari kelas eksperimen dengan modul adalah 82,142

Dari kedua nilai tersebut yang menunjukkan nilai rata-rata terbesar dari hasil belajar adalah eksperimen dengan menggunakan modul sebagai media belajarnya. Sedangkan kelas kontrol yang menggunakan metode ekspositori mendapat nilai yang masih kurang, dengan nilai mean yang rendah.

\section{Pembahasan}

Kelas kontrol, kelas eksperimen dengan modul memiliki nilai sig kurang dari 5\% artinya kedua eksperimen atau metode belajar memiliki perbedaan. Dari hasil analisis output data dengan SPSS di atas diperoleh nilai mean dari kelas kontrol adalah 57,667 , serta nilai mean dari kelas eksperimen dengan modul adalah 82,142. Pada tabel Anova terlihat sig $=0,000$ kurang dari 5\% maka signifikan Ho ditolak artinya terdapat perbedaan antara kelas kontrol, kelas eksperimen.

\section{Ketuntasan Belajar}

Dari hasil analisis di atas tampak bahwa pendekatan Group Study berbantuan modul dapat dikatakan mencapai ketuntasan dalam belajar, terutama dalam kenampakan alam dan buatan. Jadi pembelajaran berbantuan modul menunjukkan bahwa kemampuan siswa dalam memahami pelajaran dengan berbagai macam metode pembelajaran masih bervariasi. Hal ini diperlihatkan bahwa kebanyakan kelas kontrol mendapatkan nilai 54, kelas eksperimen dengan modul mendapatkan nilai 80.

Kelas kontrol belum mengalami ketuntasan belajar, akan tetapi kelas eksperimen dengan modul mengalami ketuntasan belajar. Adapun faktor-faktor yang mempengaruhi kelas kontrol belum mengalami ketuntasan belajar antara lain: (1) siswa mampu berpikir secara logis tanpa kehadiran benda-benda konkret, dengan kata lain siswa sudah mampu melakukan abstraksi tetapi, kemampuan anak dalam berpikir secara abstrak masih belum berkembang sepenuhnya sehingga dalam berbagai hal siswa masih memerlukan bantuan media.(2) pembelajaran sesuatu pengetahuan yang direpresentasikan dalam bentuk bayangan visual,gambar, yang menggambarkan kegiatan konkret atau situasi konkret. (3) pembelajaran yang direpresentasikan dalam bentuk simbol-simbol abstrak, yaitu simbol-simbol (4) siswa belajar melalui keterlibatan aktif dengan konsep-konsep dan prinsipprinsip dalam memecahkan masalah dan guru berfungsi sebagai motivator bagi siswa dalam mendapatkan pengalaman yang memungkinkan mereka menemukan dan memecahkan masalah. 


\section{Pengaruh Keaktifan, keterampilan proses, motivasi Terhadap Hasil Belajar}

Motivasi yang ada pada diri setiap orang itu memiliki ciri-ciri tertentu. Berikut ini adalah ciriciri motivasi yang diungkapakn oleh Sardiman (2005): a Tekun menghadapi tugas. b.Ulet menghadapi kesulitan. c. Menunjukkan minat terhadap macam-macam masalah. d. Lebih senang bekerja mandiri. e. Cepat bosan pada tugas-tugas yang rutin. f. Dapat mempertahankan pendapatnya. g. Tidak mudah melepaskan hal yang diyakini.

Menurut Purwanto (2004), motivasi mengandung tiga komponen pokok, yaitu menggerakkan/kebutuhan, mengarahkan/tujuan dan menopang tingkah laku manusia/dorongan. Kebutuhan terjadi bila individu merasa ada ketidakseimbangan antara yang ia miliki dengan apa yang ia harapkan. Dorongan merupakan kekuatan mental untuk melakukan kegiatan dalam rangka memenuhi harapan atau pencapaian tujuan. Dorongan yang berorientasi pada tujuan adalah inti dari motivasi.

\subsection{Group Study berbantuan modul}

Nilai $R$ square menunjukkan besarnya kontribusi $X$ yaitu motivasi, keterampilan, keaktifan siswa terhadap $Y$ nilai hasil belajar. Dari tabel di atas dapat dilihat nilai $R^{2}=0,49=4,9 \%$, artinya motivasi, keterampilan, keaktifan siswa mempengaruhi hasil belajar sebesar 4,9\%.

\section{Pengaruh Strategi Group Study Berbantuan Modul Dan Pembelajaran Ekspositori Terhadap Hasil Belajar}

Nilai mean dari kelas kontrol adalah 57,6667, nilai mean dari kelas eksperimen dengan modul adalah 82,142. Dari kedua nilai tersebut yang menunjukkan nilai rata-rata terbesar dari hasil belajar adalah eksperimen dengan menggunakan modul. Sedangkan kelas kontrol yang menggunakan metode ekspositori mendapat nilai yang masih kurang, dengan nilai mean yang lebih rendah.

Kelas kontrol, kelas eksperimen dengan modul memiliki nilai sig kurang dari 5\% artinya kedua ekperimen atau metode belajar memiliki perbedaan, terlihat dari nilai rata-rata yang diperoleh Kelas eksperimen dengan modul memiliki nilai lebih tinggi diantara kedua perlakuan.

\section{KESIMPULAN}

1. Ada perbedaan hasil belajar IPS antara pembelajaran dengan model Group Study berbantuan modul dengan model ekspositori

2. Keaktifan, keterampilan proses yang ditumbuhkan dalam belajar dengan Group Study berbantuan modul berpengaruh terhadap hasil belajar pada materi kenampakan alam dan buatan

3. Ada perbedaan motivasi siswa dalam belajar dengan model Group Study berbantuan modul dengan model ekspositori. Motivasi,keterampilan dan kektifan siswa mempengaruhi hasil belajar sebesar $4,9 \%$

4. Terjadi ketuntasan belajar pada siswa yang belajar dengan model Group Study berbantuan modul, sedangkan pada siswa yang belajar dengan ekspositori tidak.

\section{SARAN}

1. Dalam pembelajaran IPS di SD khususnya, guru disarankan memilih strategi pembelajaran yang sesuai dengan karakteristik siswa dan materi pelajaran, sebagai alternatif Quantum Teaching berbantuan modul 
2. Guru perlu mempersiapkan bahan ajar yang menunjukkan aplikasi teknologi antara lain dengan modul, untuk lebih memotivasi siswa dalam belajar.

3. Disarankan kepada peneliti lain, hendaknya penelitian ini dapat dijadikan sebagai bahan rujukan untuk penelitian yang sejenis.

\section{REFERENSI}

De Porter, B \& Mike H. (2007). Quantum learning membiasakan belajar nyaman dan menyenangkan. Bandung: KAIFA.

De Porter, B, et al. (2007). Quantum teaching mempraktekkan quantum learning di ruang-ruang kelas. Bandung: KAIFA.

Jarolimek, J. (1996). Social studies in elementary education. Seventh edition. New York: Maemillan Publishing Company.

Kosasih, D. (1995). Dasar dasar metodologi pengajaran. Bandung: Lab pengajaran PMP IKIP Bandung.

Nasution, S. (2003). Berbagai pendekatan dalam proses belajar dan mengajar. Jakarta: Bumi Aksara.

Shcunke, G.M. (1988). Elementary social studies: Knowing, doing, caring. New York: Pitman Publishing Corporation.

Silberman, M. (2001). Active learning 101 strategi pembelajaran aktif. Yogyakarta: Yappendis.

Solihatin, E., \& Raharjo. (2007). Cooperative learning. Jakarta: Bumi Aksara.

Sudjana, N., \& Ahmad R. (2002). Media pengajaran. Bandung: Sinar Baru Algensindo.

Waterwort, P. (2000). The spirit of cooperation: Using cooperative learning strategies in teacher education in Australia and Thailand. Thailand: UNESCO-ACEID. 